\title{
EXTENDING HoOsier Hospitality To LGBTQ YOUTH: Why INDIANA SHOULd PASS A CONVERSION THERAPY BAN to Protect and Promote Mental Health OUTCOMES FOR LGBTQ YOUTH
}

\author{
WARREN CANGANY*
}

\section{INTRODUCTION}

My sessions . . . focused on becoming a "proper woman." I was told to become more submissive. I remember her saying, "It's really a blessing we took you out of your leadership roles so guys will be more attracted to you." The [other] woman focused on changing my physical appearance through feminine clothing and makeup. I soon developed an eating disorder: I don't have a choice in attending these sessions, I thought, but at least I can control what I eat and throw up. ${ }^{1}$

Gay, lesbian, bisexual, and transgender youth, as well as adolescents questioning their gender identity, gender expression, or sexual orientation ("LGBTQ") "experience significant health and behavioral health disparities. Negative social attitudes and discrimination related to an individual's LGBTQ identity contribute to these disparities, and lead to individual stressors that affect mental health and well-being." "Today's LGBTQ youth face a variety of stressors - harassment, family and peer rejection, bullying from their peers, isolation and a lack of a sense of belonging - that have a major impact on their overall well-being." 3 Along with these challenges, LGBTQ youth also face the same age-related developments that accompany adolescence for all youth. ${ }^{4}$ These challenges include, but are not limited to, processing and expressing gender identity, romantic attraction, and physical changes experienced through puberty. ${ }^{5}$ However, unlike their heterosexual peers, LGBTQ youth must navigate

* J.D. Candidate, 2021, Indiana University Robert H. McKinney School of Law; B.A., 2011, DePauw University. Thank you to my family, friends, and the Indiana Health Law Review for their support throughout this writing process. A special thank you to my Note advisor, Professor Jennifer A. Drobac, Samuel A. Rosen Professor of Law at the Indiana University Robert H. McKinney School of Law, for her thoughtful and constructive insight throughout the writing process.

1. Amanda Loucks, I Survived Conversion Therapy, AdvocATE (Aug. 9, 2018), https://www.advocate.com/commentary/2018/8/09/i-survived-conversion-therapy [https://perma.cc/BJ56-J3FH] (describing mandatory and weekly conversion therapy sessions).

2. Substance Abuse \& Mental Health Servs. Admin., Ending Conversion Therapy: SuPPorting AND AFFIRMING LGBTQ Youth 1 (2015) [hereinafter SAMHSA].

3. Human Rights CAmpaign, 2018 LGBTQ Youth RePORT 6 (2018), https://assets2.hrc. org/files/assets/resources/2018-YouthReport-NoVid.pdf?_ga=2.61088296.526363940.1570234928658909893.1566136340 [https://perma.cc/QD74-UPZN].

4. SAMHSA, supra note 2 , at 2.

5. $I d$. 
awareness and acceptance of an oftentimes socially marginalized sexual identity or gender expression on top of being a normal adolescent. And, for some LGBTQ youth, this minority identity forces them to navigate adolescence without the support of family, local community, or society. This type of chronic stress has become known as minority stress among social scientists. ${ }^{6}$ It is a high level of stress associated with stigmatized minority groups and has increasingly been linked to damaging mental health outcomes. ${ }^{7}$ Comparing these challenges with those of heterosexual peers, LGBTQ youth are at an increased risk for psychological distress and substance abuse behaviors, including depressive symptoms, increased rates of substance use and abuse, suicidal ideation and attempts, as well as increased likelihood of experiencing victimization, violence, and homelessness. ${ }^{8}$

A recent national survey of 12,000 plus youth conducted by the Human Rights Campaign ("HRC") in 2018 revealed that $77 \%$ reported feeling depressed, $95 \%$ reported having trouble sleeping at night, more than $70 \%$ reported feeling worthless and hopeless, and $67 \%$ reported overhearing negative comments regarding LGBTQ people in their home. ${ }^{9}$ The HRC notes that parents and families play an essential role in promoting adolescent health and well-being, and LGBTQ youth that have a family that supports them and accepts their sexual or gender minority identity positively correlates with higher reporting of greater self-esteem and overall lower risk of negative health outcomes such as "depression, distress, hopelessness, and substance use." "10

While advocating for inclusion and acceptance for LGBTQ youth does promote more awareness and better overall outcomes, it simply is not enough. LGBTQ youth need protection under the law against practices that will be detrimental to their safety and health. This includes anti-discrimination legislation, anti-bully legislation, and a ban on the practice of conversion therapy by licensed mental health providers ("LMHPs"). This Note's focus narrows on the legislative efforts to protect and support LGBTQ youth. Specifically, it considers the impact of a ban on conversion therapy in the State of Indiana. It demonstrates that such a ban will lead to better mental health outcomes and overall better health outcomes generally for Hoosier LGBTQ youth.

"[C]onversion therapy - efforts to change an individual's sexual orientation, gender identity, or gender expression - is a practice not supported by credible evidence and has been disavowed by behavioral health experts and associations." Individuals subjected to conversion therapy experience long-term

6. Jessica Cerretani, Pattern Constraints, HARv. MED., https://hms.harvard.edu/magazine/ lgbtq-health/pattern-constraints [https://perma.cc/9ZS7-DTF3] (last visited Dec. 19, 2020).

7. Id.

8. Id.

9. See Human Rights Campaign, supra note 3, at 4-7 (providing responses from 12,005 youth aged thirteen to seventeen who identify broadly as lesbian, gay, bisexual, transgender, and/or queer from all fifty states in the United States and the District of Columbia).

10. Id. at 4 .

11. SAMHSA, supra note 2 , at 7 (footnote omitted). 

TO LGBTQ YOUTH

harm, which includes "higher rates of depression, suicidal thoughts, and suicide attempts and lower educational achievement, lower income, and lower work performance into young adulthood." " A ban on conversion therapy in the State of Indiana for minor children will also prevent uninformed parents or guardians from seeking out the detrimental practice and subjecting their child to irreparable harm. "Often these well-meaning parents choose an option that is destructive to their child and family relations because they trust practices that are misleadingly labeled as 'therapy' or 'treatment."'13 The practice is especially damaging for younger children with studies revealing children exposed to gender expression conversion therapy before the age of ten are four times more likely to attempt suicide. $^{14}$ If conversion therapy is labeled as illegal, well-meaning and uninformed parents or guardians might pause before attempting to change their minor child. ${ }^{15}$

In 2018, the HRC released a letter signed by national organizations representing millions of mental health care professionals, educators, and child welfare advocates backing legislative efforts to ban the discredited practice of conversion therapy throughout the United States. ${ }^{16}$

We emphasize the dangers of sexual orientation and gender identity change efforts, particularly for youth, which include increased risk of anxiety, depression, decreased self-esteem, social withdrawal and isolation, homelessness, substance abuse, and suicidality.

Sexual orientation and gender identity change efforts present additional, preventable risk factors to LGBT youth, a group that is already at heightened risk for suicide. ${ }^{17}$

The following professional organizations have issued statements opposing the use of conversion therapy on minors: American Academy of Child and

12. Cerretani, supra note 6 .

13. Human Rights Campaign, Just as They Are: Protecting Our Children from the Harms of Conversion Therapy 4 (2017) [hereinafter Just as They Are].

14. Cerretani, supra note 6.

15. Leila Fadel, Activists and Suicide Prevention Groups Seek Bans on Conversion Therapy for Minors, NPR (Apr. 26, 2019), https://www.npr.org/2019/04/26/716416764/activists-andsuicide-prevention-groups-seek-bans-on-conversion-therapy-for-minors [https://perma.cc/YB49WATU].

16. Stephen Peters, Mental Health, Child Welfare \& Education Orgs Back Legislative Efforts to Protect LGBTQ Youth, Hum. RTs. CAMPAign (Apr. 17, 2018), https://www.hrc.org/pressreleases/national-child-welfare-orgs-back-legislative-efforts-to-protect-lgbtq-youth [https://perma.cc/N4U7-H5L3].

17. Letter from the Am. Acad. of PAs et al. (Apr. 17, 2018), https://assets2.hrc.org/files/ assets/resources/National_Orgs_Letter_in_Support_of_Legislative_Efforts_to_End_Conversion _Therapy.pdf?_ga=2.28596284.1818856687.1602211879-1707161046.1602211879 [https://perma.cc/Q8JP-4A39] (emphasis added). 
Adolescent Psychiatry, American Academy of Pediatrics, American Association for Marriage and Family Therapy, American College of Physicians, American Counseling Association, American Medical Association, American School Health Association, American Psychoanalytic Association, American Psychiatric Association, American Psychological Association, American School Counselor Association, and National Association of Social Workers. ${ }^{18}$ However, despite the overwhelming support from major medical and mental health organizations, innocent children are still being forced into the so-called therapy by LMHPs.

While a conversion therapy ban will not solve nor completely close the gap between mental health outcomes and health outcomes in general between LGBTQ youth and their heterosexual peers, its impact will make a difference. "Studies have identified higher rates of psychological distress and psychiatric disorders among LGBTQ adults who live in U.S. states that banned same-sex marriage . . . . Likewise, state laws that permit the refusal of services to LGBTQ people ... have had damaging psychological effects." 19 A conversion therapy ban not only will protect LGBTQ youth, but also, through its expressed impact, promote the reduction of minority stress in LGBTQ youth. Indiana has the opportunity to be a trailblazer among states to protect and support vulnerable LGBTQ youth. LGBTQ youth subjected to the harmful practices of conversion therapy are eight times more likely to attempt suicide, six times more likely to report high levels of depression, three times more likely to use illegal drugs, and three times more likely to engage in risky sexual behaviors that lead to a higher risk of human immunodeficiency virus and sexually transmitted diseases. ${ }^{20}$ The disparity in mental health outcomes, and health outcomes generally, between LGBTQ youth and their heterosexual peers is a health care concern. Therefore, Indiana must protect LGBTQ youth by banning conversion therapy provided by uninformed LMHPs to promote and protect LGBTQ youth in the Hoosier State.

\section{A. The Issue: Indiana's Failure to Protect LGBTQ Youth}

In January of 2019, Indiana politicians introduced two bills to ban the practice of conversion therapy by licensed medical professionals. ${ }^{21}$ Advocates of the bans stated that the bills would not cost the State any money and were not uncommon bills. ${ }^{22}$ However, Micah Clark, president of the American Family Association of Indiana, a socially conservative organization, challenged the bans.

18. Christy Mallory ET AL., UCLA Sch. L. Williams Inst., CONVERSion TheraPy AND LGBT Youth: Update 9 n.17 (2019).

19. Cerretani, supra note 6.

20. The Lies and Dangers of Efforts to Change Sexual Orientation or Gender Identity, Hum. RTS. CAMPAIGN, https://www.hrc.org/resources/the-lies-and-dangers-of-reparative-therapy [https:// perma.cc/5C2J-KL4S] (last visited Dec. 19, 2020) [hereinafter Lies and Dangers].

21. Kaitlin Lange, Lawmakers Propose Ban on Conversion Therapy for Minors, INDY STAR (Jan. 9, 2019), https://www.indystar.com/story/news/politics/2019/01/09/lawmakers-proposesexual-orientation-conversion-therapy-ban/2514253002/ [https://perma.cc/2D2X-JPRT].

22. Id. 
He claimed the bills would infringe on medical providers' First Amendment rights, more narrowly their freedom of speech. ${ }^{23}$

Senator Mark Stoops introduced Senate Bill 284 to amend the Indiana Code to prohibit the practice of conversion therapy on LGBTQ minors in the State of Indiana. ${ }^{24}$ The bill aimed to amend section 25-23.6-11 of the Indiana Code by adding language that prohibited LMHPs from engaging in the practice of conversion therapy with a patient under the age of eighteen. ${ }^{25}$ The bill also expressly stated that any LMHP who engaged in conversion therapy on a minor would be subject to disciplinary action. ${ }^{26}$ Stoops argued that the bill was necessary because LMHPs should not make minors feel unwanted or isolated, especially when LGBTQ youth are more likely to experience negative mental health outcomes. ${ }^{27}$ The bill did not gain any momentum and failed before any committee meetings.

Indiana House Bill 1231 was also introduced at the same time as Senate Bill $284{ }^{28}$ The bill, which was submitted by Representative Chris Chyung, called for a ban on the practice of conversion therapy by LMHPs in the State of Indiana. ${ }^{29}$ House Bill 1231 used the exact language as Senate Bill 284, and it attempted to amend Indiana Code provisions that regulate professional marriage and family therapists by adding conversion therapy to the chapter of prohibited practices. ${ }^{30}$ Chyung reasoned, "This was one of those things that we saw was a real opportunity to show all Hoosier kids that they're welcome in this [S]tate." ${ }^{\prime 1}$ The bill did not advance past the introduction phase. ${ }^{32}$

Ultimately, both bills failed because the protection of LGBTQ youth is not a high priority in Indiana. Also, a ban on conversion therapy is currently a stigmatized topic in the State. However, a 2019 report found that Hoosier youth are significantly more likely to consider or attempt suicide than their peers in other states. ${ }^{33}$ One in five Hoosier LGBTQ youth considers suicide. ${ }^{34}$ Hoosier youth who identify as a sexual orientation minority are five times more likely to attempt suicide than their heterosexual peers. ${ }^{35}$ Youth in Indiana, regardless of

23. See U.S. Const. amend. I; Lange, supra note 21.

24. Lange, supra note 21.

25. S.B. 284, 121st Gen. Assemb., 1st Reg. Sess. (Ind. 2019).

26. Id.

27. See Lange, supra note 21.

28. See id.; H.B. 1231, 121st Gen. Assemb., 1st Reg. Sess. (Ind. 2019).

29. Lange, supra note 21.

30. H.B. 1231.

31. Lange, supra note 21.

32. H.B. 1231.

33. Ind. Youth Inst., 2019 Indiana Kids Count Data Book: A Profile of Hoosier Youth 126 (2019), https://s3.amazonaws.com/iyi-website/data-book/2019+Data+book+/2019_ IYI_Databook_022619.pdf [https://perma.cc/F3GY-9QPS].

34. Id.

35. Id. at 127. 
whether or not they identify as LGBTQ, are taking their own lives at alarming rates compared to their peers in other states. ${ }^{36}$ Indiana missed an opportunity to be an advocate for its youth to promote a healthier and happier state, which includes LGBTQ youth living in the State.

\section{B. An Argument for Reform}

This Note advocates for a ban on conversion therapy practices by LMHPs and for the protection of LGBTQ youth's mental health outcomes. It discusses the statutes and bills passed by other states to ban the practice of conversion therapy by licensed medical providers. Section II reviews the historical background of the rise and development of conversion therapy in the United States. Section III offers an analysis of the different conversion therapy bans passed in the United States. Specifically, this Note focuses on California and New Jersey laws, as well as the HRC's call for a complete ban on conversion therapy. Section IV argues that Indiana has a duty to adopt a conversion therapy ban because no empirical evidence proves that conversion therapy works. Indiana must regulate LMHPs. Indiana also has a duty to protect LGBTQ youth. Finally, Section V advocates that Indiana must pass legislation banning the practice of conversion therapy by LMHPs and protect LGBTQ youth in the State.

\section{BACKGROUND}

The first step - which usually lasted six months - is where they "deconstruct us as a person." Their tactics still haunt me. Aversion therapy, shock therapy, harassment and occasional physical abuse. Their goal was to get us to hate ourselves for being LGBTQ .... The second step of the program, they "rebuilt us in their image." They removed us of everything that made us a unique person, and instead made us a walking, talking, robot for Jesus. They retaught us everything we knew. How to eat, talk, walk, dress, believe, even breathe. We were no longer people at the end of the program. ${ }^{37}$

\section{A. The Development of Conversion Therapy}

Up until the 1970s, homosexuality was deemed by the American Psychiatric Association to be a certified mental disorder. ${ }^{38}$ In 1973, however, the American Psychiatric Association removed it from the Diagnostic and Statistical Manual of Mental Disorders. ${ }^{39}$ Leading up to that declaration, emerging scientific

36. See generally id.

37. James Michael Nichols, A Survivor of Gay Conversion Therapy Shares His Chilling Story, HufFPost (Nov. 17, 2016), https://www.huffpost.com/entry/realities-of-conversion-therapy_ n_582b6cf2e4b01d8a014aea66 [https://perma.cc/W6RA-6AU3].

38. SAMHSA, supra note 2 , at 15.

39. Judith M. Glassgold et Al., Am. Psychol. Ass'n, Report of the American 

TO LGBTQ YOUTH

evidence and social awareness advocated for the end of sexual orientation discrimination. ${ }^{40}$ The effort was led by the American Psychiatric Association and other professional organizations to affirm that homosexuality was not a mental disorder and rejected the stigma of mental illness that medical and mental health professions had previously placed on sexual orientation minorities. ${ }^{41}$ This change propelled many mental health providers to begin to adopt the position that homosexuality was a normal variation in human sexuality and that sexual minority identities should be affirmed. ${ }^{42}$ However, despite the affirmation by the American Psychiatric Association regarding homosexuality, many sexual orientation minorities still faced discrimination and were subjected to outdated social prejudices.

For years, LGBTQ people have been told that they are abnormal. This negative belief gave birth to the idea that LGBTQ people can also be changed or converted to heterosexual or cisgender through what is commonly referred to as conversion therapy, reparative therapy, or sexual orientation change efforts ("SOCE"). ${ }^{43}$ This Note will use conversion therapy and SOCE interchangeably. The practice of conversion therapy aims to alter a core component of a person's identity and attempts "to change a person's identity from trans- to cisgender or their orientation from LGB to heterosexual." ${ }^{44}$ The practice of conversion therapy has been documented in academic literature as early as the $1890 \mathrm{~s} .{ }^{45}$ The practice became common during the 1950s and the 1960s at a time when homosexuality was still branded as a mental disorder. ${ }^{46}$ The mental illness classification gave rise to the notion that it needed to be cured. ${ }^{47}$ The first attempts to cure homosexuality included "reversing the effects of pathogenic genetic defects, flawed or excessive parenting, and lasting trauma from sexual abuse" because the cure was based on the idea that reversing those factors would remove individual blocks to heterosexuality. ${ }^{48}$

Over time, the techniques therapists used to try to change sexual orientation and gender identity developed into more drastic and devastating medical measures. These toxic so-called therapy techniques included "inducing nausea, vomiting, or paralysis; providing electric shocks; or having the individual snap

PSYCHOLOGICAL ASSOCIATION TASK ForCE ON APPROPRIATE THERAPEUTIC RESPONSES TO SEXUAL ORIENTATION 11 (2009).

40. Id.

41. Id.

42. Id.

43. Id. at 71 n.61; SAMHSA, supra note 2, at 64 (defining cisgender as "[a] person whose gender identity, gender expression, and sex assigned at birth all align.”).

44. Cerretani, supra note 6.

45. MALlORY ET AL., supra note 18, at 2.

46. GLASSGOLD ET AL., supra note 39.

47. McDermott Will \& Emery LlP, The Pernicious Myth of Conversion Therapy: How Love in Action Perpetrated a Fraud on America 3 (2018).

48. Id. 
an elastic band around the wrist when the individual became aroused to same-sex erotic images or thoughts. Other examples of aversive behavioral treatments included" using shame to create an aversion to same-sex attractions; orgasmic reconditioning; and satiation therapy. ${ }^{49}$ Unfortunately, the federal government also supported the conversion therapy efforts by providing funding to St. Elizabeths Hospital, which was also known as the "Government Hospital for the Insane," where LGBTQ individuals were subjected to invasive surgical procedures, such as an ice pick lobotomy in hopes of curing homosexuality. ${ }^{50}$ This barbaric procedure included, "an instrument [being] inserted through the eye socket to detach the frontal lobe of the brain from the hypothalamus, believed to be the source of irrationality." 51 These cruel techniques, which many would consider to be torture, not only had a detrimental impact on the LGBTQ individual's mental health but also led to negative physical health outcomes. The belief of conversion therapy paved the way for perpetuating the negative societal stigmas surrounding the LGBTQ community. ${ }^{52}$

Despite the declassification of homosexuality as a mental disorder in 1973, the notion that homosexuality could be cured had become embedded in American culture. And after the American Psychiatric Association declared that homosexuality was not a mental disorder, Love in Action ("LIA") took on the mission of curing LGBTQ Americans. ${ }^{53}$ LIA redeveloped the techniques commonly associated with conversion therapy and implemented techniques that consisted of biblical teachings, spiritual discipline, and a twelve-step program designed to heal. ${ }^{54}$ The founder of the LIA sought out LMHPs to staff his programs to promote the idea that his program was credible, despite the American Psychologists Association's ("APA") position against conversion therapy. ${ }^{55}$ LIA employed LMHPs with the right credentials who also agreed with LIA's mission and philosophies of curing LGBTQ individuals. ${ }^{56}$

In the twenty-first century, LGBTQ youth are realizing and disclosing their minority sexual orientation or identifying as lesbian, gay, or bisexual at younger ages than in previous generations. ${ }^{57}$ While this trend of LGBTQ youth coming out earlier speaks to society's acceptance of the LGBTQ community, it creates a larger vulnerable population that may be subjected to conversion therapy. ${ }^{58}$ In the early 1990s, the APA noticed the "resurgence of individuals and organizations that actively promoted the idea of homosexuality as a developmental defect or a

49. GLASSGOLD ET AL., supra note 39, at 22.

50. MCDERmott WiLl \& EMERy LLP, supra note 47, at 6.

51. Id. at 6-7.

52. See Cerretani, supra note 6.

53. MCDERMOTt WiLl \& EMERy LLP, supra note 47, at 13.

54. Id. at 12 .

55. Id. at 16 .

56. Id.

57. SAMHSA, supra note 2 , at 2.

58. Id. 
spiritual and moral failing." ${ }^{59}$ These anti-gay organizations advocated for psychotherapy coupled with religious ministry to alter a person's feelings. ${ }^{60}$

The detrimental practice's resurgence led the APA to adopt the Resolution on Appropriate Therapeutic Response to Sexual Orientation in $1997 .{ }^{61}$ This resolution reaffirmed the conclusion "shared by all mainstream health and mental health professions that homosexuality is not a mental health disorder and rejected any form of discrimination based on sexual orientation." ${ }^{.62}$ Additionally, the resolution highlighted many ethical issues surrounding the harmful practice. "In 2009, the APA Taskforce on Appropriate Therapeutic Responses to Sexual Orientation Change Efforts concluded . . . that no methodologically-sound research on adults undergoing conversion therapy has demonstrated its effectiveness in changing" an individual's sexual orientation minority identity. ${ }^{63}$ The amount of physically abusive and physically damaging therapy techniques has drastically reduced today. ${ }^{64}$ However, conversion therapy has evolved into a talk therapy practice. ${ }^{65}$ This practice includes training a person to conform to stereotypical gender norms, teaching heterosexual dating skills, and using hypnosis to try to redirect desires. ${ }^{66}$ Although the techniques used today in conversion therapy are "less shocking and extreme," they still lack an empirical basis for accomplishing their intended goal. ${ }^{67}$ The Williams Institute at the University of California, Los Angeles School of Law (the "Williams Institute") estimated that 698,000 LGBTQ adults have been subjected to conversion therapy in their lifetime. ${ }^{68}$ This figure includes 350,000 LGBTQ adults who experienced detrimental brainwashing during adolescence. ${ }^{69}$

\section{CONVERSION THERAPY BANS IN THE UNITED STATES}

The therapist ordered me bound to a table to have ice, heat and electricity applied to my body. I was forced to watch clips on a television of gay men holding hands, hugging and having sex. I was supposed to associate those images with the pain I was feeling to once and for all turn into a straight boy. In the end it didn't work. I would say that it did, just to make the pain go away. ${ }^{70}$

59. GLASSGOLD ET AL., supra note 39, at 12.

60. Id.

61. Id.

62. Id.

63. SAMHSA, supra note 2, at 25.

64. JUST AS TheY ARE, supra note 13, at 7.

65. Id.

66. Id.

67. Id.

68. MALlORY ET AL., supra note 18.

69. Id.

70. Sam Brinton, I Was Tortured in Gay Conversion Therapy. And It's Still Legal in 41 
Conversion therapy has been disavowed by all leading behavioral health experts and health providers. "Conversion therapy perpetuates outdated views of gender roles and identities as well as the negative stereotype that being a sexual or gender minority or identifying as LGBTQ is an abnormal aspect of human development." ${ }^{\text {"71 }}$ Conversion therapy is also a practice that is not supported by credible empirical evidence and has been rejected by behavioral health experts and associations. ${ }^{72}$ Moreover, conversion therapy puts young LGBTQ people at risk of serious harm and continues to destroy the lives of not only LGBTQ individuals but also their families and communities. ${ }^{73}$ "Sometimes [conversion therapy is] the conscious choice of loving parents who think they're doing what is best for their child but who lack accurate information about its inefficacy and dangers." 74

\section{A. Popular Culture Prompts Legislative Change}

Conversion therapy found its way into popular culture in 2016 when Garrard Conley released his memoir recounting his experience with conversion therapy as a teenager ${ }^{75}$ At age nineteen, Conley was forced into an LIA program because his parents could not accept his gay identity.$^{76}$ LIA operated on the misconception that "homosexuality meant unhappiness, isolation and death." "While enduring LIA's brainwashing, Conley witnessed a mock funeral for a "defector," which included other patients reading the defector's obituary. ${ }^{78}$ LIA attempted to control every aspect of Conley's life: where he went, who he spoke to, his grooming habits, and dress code. ${ }^{79}$ Conley was able to escape the program along with his LIA handbook, which detailed the destructive techniques. ${ }^{80}$ The novel was adapted into a Golden Globe-nominated film in 2018 starring Nicole Kidman, Russell Crowe, and Lucas Hedges.$^{81}$ Conley's memoir and the film brought awareness to the discredited practice and evoked a call to action around the nation. Most recently, the film inspired Republican Kentucky Senator Alice

States., N.Y. TimES (Jan. 24, 2018), https://www.nytimes.com/2018/01/24/opinion/gay-conversiontherapy-torture.html [https://perma.cc/7PCE-Y9B2].

71. SAMHSA, supra note 2 , at 1 .

72. Id. at 7 .

73. Julie Laemmle, California's Conversion: A Ban on Minor Conversion Therapy and the Effect on Other States, 2 InD. J.L. \& Soc. EQuALITY 248, 254 (2013).

74. Just As They ARE, supra note 13, at 4.

75. See Garrard Conley, Boy Erased: A Memoir (2016).

76. Aaron Hicklin, I Was 19, Gay and Ready to Be 'Cured' by Conversion Therapy, GUARDIAN (June 10, 2018), https://www.theguardian.com/lifeandstyle/2018/jun/10/i-was-19-gayand-ready-to-be-cured-by-conversion-therapy [https://perma.cc/N7ZT-Q3UJ].

77. Id.

78. Id.

79. Id.

80. Id.

81. Boy Erased (Perfect World Pictures 2018). 
Forgy Kerr, a conservative Christian, to advocate for a ban in Kentucky in 2020 after witnessing the terrible treatment of Conley in the film. ${ }^{82}$ Conversion therapy again emerged into popular culture in the film The Miseducation of Cameron Post $^{83}$ This movie portrayed a high school girl subjected to conversion therapy practices. ${ }^{84}$ In 2019, Lifetime released a made-for-TV movie, Trapped: the Alex Cooper Story based on the memoir by Alex Cooper, which depicted the harsh and brutal realities of the unregulated practice of conversion therapy ${ }^{85}$ Cooper, a California native, was only fifteen-years-old when she came out as gay to her Mormon family ${ }^{86}$ Cooper's parents, distraught with the news, forced Cooper to Utah to stay with a family her parents believed would be able to cure her. ${ }^{87}$ Cooper's parents signed the proper guardianship documents to allow the family to enroll Cooper into school while staying in Utah and left Cooper with the family against her will - helpless. ${ }^{88}$ Cooper spent eight months with the family who attempted to cure her through physically and verbally abusive measures. ${ }^{89}$ In Cooper's devastating memoir, she recalled standing for hours in front of a wall while wearing a backpack full of rocks for days on end, which led her to contemplate suicide. Cooper wrote:

I just could not do it anymore. I had always had a fighting spirit. Even my suicide attempt was in its own way part of my fight to control who I was and where my life would take me. My fighting spirit had gotten me into trouble at times, to be sure. But now I could feel something in me surrendering and lying down. ${ }^{90}$

Cooper eventually was able to break free from the family holding her captive in Utah. ${ }^{91}$ Cooper released her memoir in 2016 with hopes that it would bring attention to the detrimental practice of conversion therapy and would help motivate more states to ban the practice. ${ }^{92}$ Cooper has since been able to reconcile

82. Trudy Ring, A Kentucky Republican with a Gay Son Wants to Ban Conversion Therapy, AdvocAte (Jan. 20, 2020), https://www.advocate.com/politics/2020/1/30/kentucky-republicangay-son-wants-ban-conversion-therapy [https://perma.cc/NX9M-VCHE].

83. The Miseducation of Cameron Post (Parkville Pictures 2018).

84. Id.

85. Trapped: the Alex Cooper Story (Silver Screen Pictures 2019); see also Alex CoOper \& JoAnna Brooks, SAving Alex: When I Was Fifteen, ITold My Mormon Parents I WAS GAy, AND THAT'S WHEN My NightMARE BEgAn (2016).

86. See COOPER \& BROOKS supra note 85 .

87. See id.

88. See id.

89. See id.

90. Id. at 123-24.

91. Id.

92. Elizabeth Daley, Teen Forced to Carry Rocks to 'Cure' Her Lesbianism, ADvocATE (Mar. 17, 2016), https://www.advocate.com/religion/2016/3/17/teen-forced-carry-rocks-cure-herlesbianism [https://perma.cc/F5QV-HWKB]. 
with her parents after they abandoned her with the Utah family when she was just fifteen-years-old. ${ }^{93}$ Conley and Cooper hope their memoirs will bring awareness to the practice of conversion therapy and will make parents think twice before forcing their children into the practice. "They thought they were doing the best thing for me .... I think that's what a lot of parents are under the impression of, that they're doing the best thing for their child." ${ }^{\circ 4}$ Conley and Cooper's stories reflect an all too common experience for LGBTQ youth, who are coerced by family members to undergo the damaging practices. $^{95}$

In early 2020, conversion therapy reemerged into mainstream media when Bowen Yang became the first celebrity to share his personal struggle of being forced into conversion therapy as a teenager with The New York Times. ${ }^{96}$ As the newest cast member and first openly gay Chinese-American to appear on "Saturday Night Live," Yang used his newfound fame to share his struggle with the life-shattering practice. ${ }^{97}$ Yang was outed to his conservative Chinese parents when he was just seventeen-years-old after they discovered an AOL Instant Message conversation between him another man. ${ }^{98}$ Yang recalled the painful experience, "I'd only seen my father cry when my grandpa died and now he's sobbing in front of me every day at dinner .... This is the worst thing you can do as a child of immigrants. It's just like you don't want your parents to suffer this much over you." 99 Soon after the tearful family meeting, Yang's father enrolled Yang into an eight-session conversion therapy program in Colorado Springs. ${ }^{100}$ Yang completed the program, which he recalled used talk therapy and shaming. ${ }^{101}$ Like many other young LGBTQ youths coerced into the detrimental practice, the feeling of family rejection outweighed the present-perceived harm. ${ }^{102}$ Yang went on to attend New York University where he realized he would not be able to ignore his same-sex feelings and that conversion therapy did not cure

93. Curtis M. Wong, Mormon Woman Exposes Barbaric And 'Humiliating' Treatment For Being Gay, HuffPost (Mar. 17, 2016), https://www.huffpost.com/entry/saving-alex-mormonteen_n_56ead60ee4b09bf44a9c9152?guccounter=1\&guce_referrer $=$ aHR0cHM6Ly93 d3cuZ29v Z2xlLmNvbS8\&guce_referrer_sig=AQAAACwaveNgWyDHESO9uHO9OGiysEaneHJ4v1X2 pNMHhEV20Uke8HVBDq7m1034DDTdP_6fBLsgBlZkXTwjlLPSuICU7xcDdpWoBfUiTNdX JsZWmZdTalhC3-pCKKgjh0PiRKSBdSV6OpIfuAISvK2AVSvHlByyv49owu01 VtJlrbzb [https://perma.cc/K5WH-LTFP].

94. Daley, supra note 92.

95. See Wong, supra note 93.

96. Maureen Dowd, Bowen Yan of 'S.N.L.' Is a Smash. And a Mensch., N.Y. TimES (Jan. 25, 2020), https://www.nytimes.com/2020/01/25/style/bowen-yang-snl.html [https://perma.cc/K4AA4E55].

97. Id.

98. Id.

99. Id.

100. Id.

101. Id.

102. Id.; Sanam Assil, Can You Work It? Or Flip It and Reverse It?: Protecting LGBT Youth From Sexual Orientation Change Efforts, 21 CARDOZO J.L. \& GENDER 551, 561 (2015). 
him. ${ }^{103}$ Reflecting back on his experience with conversion therapy, Yang said, "It was just crazy. Explain the gay away with pseudoscience."104

Conley, Cooper, and Yang's experiences with conversion therapy are not uncommon and also demonstrate the many different ways conversion therapy may be practiced around the United States. "Most often, young LGBT individuals do not choose to receive reparative therapy voluntarily; rather instead, their family, and mainly their parents, force them to undergo treatment because they do not want to accept that their children are gay." 105 The Williams Institute estimates that 16,000 LGBTQ youth will be forced into conversion therapy programs in states without bans. ${ }^{106}$

\section{B. Conversion Therapy Visibility Creates a Wave of Change}

Popular Culture unveiled these hidden, damaging practices of conversion therapy. Conversion therapy no longer only existed in the memories of innocent victims, devastating memoirs, or moving motion pictures. It also appeared in major publications like Vogue, Teen Vogue, The Atlantic, Time, and People. ${ }^{107}$ The spotlight on conversion therapy began an undeniable shift in conversion therapy ban legislation as many Americans began to advocate for bans. In 2018, the HRC along with numerous national medical and mental health organizations took advantage of conversion therapy's growing exposure in popular culture and called for legislative action in banning conversion therapy practices. ${ }^{108}$ Currently, twenty states, along with the District of Columbia, have banned conversion therapy practices by LMHPs on minors. To date, California, Colorado, Connecticut, Delaware, Hawaii, Illinois, Maine, Maryland, Massachusetts,

103. Dowd, supra note 96.

104. Id.

105. Assil, supra note 102.

106. MALLORY ET AL., supra note 18.

107. See Lauren Sanchez, Chloë Grace Moretz Preaches Self-Love at Last Night's New York City Premiere of The Miseducation of Cameron Post, Vogue (Aug. 2, 2018), https://www.vogue. com/article/new-york-city-premiere-the-miseducation-of-cameron-post [https://perma.cc/ZG5S3447]; see Chelsea Greenwood Lassman, How Conversion Therapy Came to Be, and How It Persists Today, TeEn Vogue (Aug. 7, 2018), https://www.teenvogue.com/ story/how-gayconversion-therapy-came-to-be-and-how-it-persists-today [https://perma.cc/JPS7-4BAZ]; see Joseph Frankel, More and More States Are Outlawing Gay-Conversion Therapy, ATLANTIC (July 10, 2017), https:/www.theatlantic.com/health/archive/2017/07/states-outlawing-conversiontherapy/533121/ [https://perma.cc/G4W5-XCZR]; see Mathew Shurka, I Did Conversion Therapy for 5 Years-Now I'm Working to End It, TIME (Oct. 27, 2015), https://time.com/4075291/ conversion-therapy/ [https://perma.cc/2K3G-4NPB]; see Caitlin Keating, Woman Recalls Being Held Against Her Will During Gay Conversion Therapy as Teen: 'I Wanted to Die,' People (Nov. 9, 2018), https://people.com/human-interest/girl-15-held-against-her-will-endured-8-months-gayconversion-therapy/ [https://perma.cc/2XMT-LTUV].

108. Just AS They ARE, supra note 13. 
Nevada, New Hampshire, New Jersey, New Mexico, New York, Oregon, Rhode Island, Utah, Vermont, Virginia, and Washington have all banned conversion therapy for minors. ${ }^{109}$ Notably, Utah is the most conservative state to pass a ban on conversion therapy. ${ }^{110}$ Utah's conversion therapy ban is an acknowledgment that a ban is a necessary step in protecting LGBTQ minors and further demonstrates that this issue crosses political lines. ${ }^{111}$ The Church of Jesus Christ of Latter-day Saints also expressed its support for the ban, which many LGBTQ advocates tied to the rising suicide rate in Utah, especially for minors. ${ }^{112}$ North Carolina has also passed a partial ban on conversion therapy through a recent executive order, which prohibits the use of state funds from being used towards supporting conversion therapy. ${ }^{113}$

\section{California Becomes the First State to Pass a Conversion Therapy Ban in the United States}

In 2012, California became the first state in the United States to pass a conversion therapy ban with Senate Bill 1172 ("SB 1172"). ${ }^{114}$ SB 1172 prohibits state-licensed health care providers from engaging in conversion therapy with minor youth under the age of eighteen-years-old. ${ }^{115}$ "Under no circumstances shall a mental health provider engage in SOCE with a patient under [eighteen] years of age." ${ }^{116}$ The ban considers the practice of conversion therapy to be "unprofessional conduct" and would subject the health care provider to "discipline by the licensing entity for that mental health provider." 117 Senator Ted W. Lieu's SB 1172 advocated that not only is conversion therapy scientifically ineffective but it also causes great harm, including rising suicide rates in LGBTQ

109. See Conversion “Therapy” Laws, Movement Advancement Project, https://www. lgbtmap.org/equality-maps/conversion_therapy [https://perma.cc/7MYU-YUKZ] (last visited Dec. 19, 2020).

110. Colin Dwyer, Utah Becomes Latest State to Ban Discredited LGBTQ 'Conversion Therapy, 'NPR (Jan. 22, 2020), https://www.npr.org/2020/01/22/798603313/utah-becomes-lateststate-to-ban-discredited-lgbtq-conversion-therapy [https://perma.cc/TB3L-CRBB].

111. Id.

112. Tara Law, Why the LDS Church Joined LGBTQ Advocates in Supporting Utah's Conversion Therapy Ban, TIME (Nov. 29, 2019), https://time.com/5741789/utah-conversiontherapy-ban-lds/ [https://perma.cc/HZ99-KCZY].

113. Tim Fitzsimmons, N. Carolina Is First in South to Ban State Funding for Conversion Therapy, NBC News (Aug. 2, 2019), https:/www.nbcnews.com/feature/nbc-out/n-carolina-firstsouth-ban-state-funding-conversion-therapy-n1038846 [https://perma.cc/J9RG-Y8DS].

114. LGBT Policy Spotlight: Conversion Therapy Bans, Movement AdVAnCEMEnt PRoject 1 (July 2017), https:/www.lgbtmap.org/file/policy-spotlight-conversion-therapy-bans.pdf [https:// perma.cc/2RP2-FP3V].

115. Id.

116. Cal. Bus. \& Prof. Code $\S 865.1$ (2020).

117. CAL. Bus. \& Prof. Code $\S 865.2$ (2020). 
youth. ${ }^{118}$

California's conversion therapy ban was challenged in Pickup v. Brown. The plaintiffs argued that SB 1172 infringed upon a therapist's protected speech rights and the parental rights of parents who sought conversion therapy for their minor children. ${ }^{119}$ The Ninth Circuit Court of Appeals held that California's conversion therapy ban did not violate the free speech rights of SOCE practitioners or minor parents. ${ }^{120}$ The Ninth Circuit failed to find that the practice of conversion therapy was protected speech, which would have triggered strict scrutiny in analyzing the bill's constitutionality. ${ }^{121}$ "Senate Bill 1172 regulates conduct. It bans a form of treatment for minors; it does nothing to prevent licensed therapists from discussing the pros and cons of SOCE with their patients. Senate Bill 1172 merely prohibits licensed mental health providers from engaging in SOCE with minors." ${ }^{122}$ The Ninth Circuit found that SB 1172 sought to regulate the medical profession and, therefore, a rational basis standard applied. ${ }^{123}$ The Ninth Circuit distinguished the bill from regulating free speech protections under the First Amendment because it did not prevent LMHPs from discussing conversion therapy with the public, expressing their personal views about the practice, recommending the practice to patients, or participating in conversion therapy with adults over the age of eighteen. ${ }^{124}$ SB 1172 regulates mental health treatment and does not regulate LMHPs' free speech. ${ }^{125}$ Further, the Ninth Circuit "conclude[d] that the First Amendment does not prevent a state from regulating treatment even when the treatment is performed through speech alone."126

The Ninth Circuit also held that the ban did not violate parents' fundamental rights furnished by the Fourteenth Amendment. ${ }^{127}$ Parental Rights were established in Meyer $v$. Nebraska when the Fourteenth Amendment was interpreted to provide parents exclusive rights when raising their children. ${ }^{128}$ The Constitution has consistently been interpreted to preserve and protect a parent's autonomy to direct the care and treatment of his or her child. ${ }^{129}$ However, despite this consistent recognition, the Supreme Court has outlined that a state may interfere with this right when it concerns the health or safety of children. ${ }^{130} \mathrm{~A}$

118. Assil, supra note 102, at 564.

119. Laemmle, supra note 73, at 262.

120. See Pickup v. Brown, 740 F.3d 1208 (9th Cir. 2014).

121. Laemmle, supra note 73, at 263.

122. Pickup, 740 F.3d at 1229.

123. Laemmle, supra note 73, at 263.

124. Pickup, 740 F.2d at 1223.

125. Id.

126. Id. at 1230 .

127. See id.

128. Meyer v. Nebraska, 262 U.S. 390, 398-400 (1923).

129. Laemmle, supra note 73, at 256.

130. Id. 
state is empowered to restrict parental rights if it is deemed necessary. ${ }^{131}$ Therefore, the Ninth Circuit held in favor of SB 1172 because it was within the power and control of the State of California to protect the health and safety of minor children. ${ }^{132}$ "[T] he fundamental rights of parents do not include the right to choose a specific type of provider for a specific medical or mental health treatment that [a] state has reasonably deemed harmful." 133 The landmark decision affirmed protections for LGBTQ youth in California, and it also reaffirmed that conversion therapy was not an acceptable mental health practice. ${ }^{134}$

\section{New Jersey Stands Up to Protect LGBTQ Minors}

In 2013, New Jersey became the second state to ban the practice of conversion therapy on LGBTQ minors. ${ }^{135}$ New Jersey passed a ban for imposing SOCE upon a person under the age of eighteen. ${ }^{136}$ Republican Governor Chris Christie stated that

on issues of medical treatment for children we must look to experts in the field to determine the relative risks and rewards. The American Psychological Association has found that efforts to change sexual orientation can pose critical health risks including, but not limited to, depression, substance abuse, social withdrawal, decreased self-esteem and suicidal thoughts. I believe that exposing children to these health risks without clear evidence of benefits that outweigh these serious risks is not appropriate. ${ }^{137}$

New Jersey's conversion therapy ban was challenged in King v. Governor of New Jersey. The Third Circuit Court of Appeals held that the State's conversion therapy ban did not violate LMHPs' First Amendment rights to free speech because New Jersey's ban regulated professional speech and not speech generally. ${ }^{138}$ The Third Circuit noted this distinction from the Ninth Circuit's ruling in 2014 by stating that "the argument that verbal communications become 'conduct' when they are used to deliver professional services was rejected . . . . Further, the enterprise of labeling certain verbal or written communications [as] 'speech' and others [as] 'conduct' is unprincipled and susceptible to

131. Id. at 257.

132. Pickup, 740 F.3d at 1236.

133. Id.

134. See Id.

135. Nancy Cutler, New Jersey Conversion Therapy Ban Stands, for Now, but LGBT Groups Expect More Challenges, Tyler CLEMENTI Found. (Apr. 19, 2019), https://tylerclementi.org/newjersey-conversion-therapy-ban-stands-for-now-but-lgbt-groups-expect-more-challenges/ [https://perma.cc/4L79-QFGB].

136. N.J. REV. STAT. § 45:1-55 (2020).

137. Just As They ARE, supra note 13.

138. See King v. Governor of New Jersey, 767 F.3d 216 (3d Cir. 2014). 
manipulation." 139

The Third Circuit made a clear distinction between a free citizen's First Amendment right to free speech and the First Amendment right to free speech furnished to licensed professionals. The Third Circuit held "that a licensed professional does not enjoy the full protection of the First Amendment when speaking as part of the practices of her profession .... [A] professional's speech warrants lesser protection only when it is used to provide personalized services to a client based on the professional's expert knowledge and judgment."140 Additionally, the Third Circuit likened professional speech to commercial speech, which is subjected to intermediate scrutiny and not the strict scrutiny standard that is typically applied to freedom of speech cases. ${ }^{141}$ The Third Circuit also emphasized that "regulation of professional speech is spared from more demanding scrutiny only when the regulation was ... enacted pursuant to [a] [s]tate's interest in protecting its citizens from ineffective or harmful professional services." ${ }^{42}$ This determination by the Third Circuit provided the foundation for the New Jersey conversion therapy ban to withstand the constitutional challenges brought by conversion therapy practitioners.

New Jersey further upheld LGBTQ rights in Ferguson v. JONAH, when a jury found in favor of a claim, which was brought under New Jersey's Consumer Fraud Act, that a conversion therapy program was fraudulent and unconscionable. ${ }^{143}$ This case distinguished itself from other conversion therapy ban challenges because it provided a monetary remedy for individuals who had previously participated in conversion therapy and suffered negatively because of it. Ferguson v. JONAH analyzed the issue from a consumer perspective. ${ }^{144}$

In Ferguson v. JONAH, the plaintiffs, who were former male participants of a conversion therapy program offered by Jews Offering New Alternatives for Healing ("JONAH"), alleged that JONAH "engaged in unconscionable practices, deception, fraud, false promises, and misrepresentations in rendering its services." ${ }^{145}$ The plaintiffs provided detailed descriptions of the individual and group therapy sessions they experienced, which included being subjected to homophobic slurs, required to remove articles of clothing in group settings while negatively talking about oneself, and subjected to counseling that suggested the plaintiffs spend more time at the gym and naked with their fathers in steam rooms. ${ }^{146}$ JONAH reportedly charged the plaintiffs $\$ 100$ for individual sessions and $\$ 60$ for group sessions, and, depending on the individual, the costs could

139. Id. at 228 .

140. Id. at 232 .

141. Id. at 234 .

142. Id. at 235 .

143. See Ferguson v. JONAH, 445 N.J. Super. 129 (N.J. Super. Ct. Law Div. 2014). The program claimed to change individuals from homosexual to heterosexual. Id.

144. See id.

145. Id. at 139 .

146. Id. at $134-35$. 
exceed over $\$ 10,000$ in one year. ${ }^{147}$

The plaintiffs asserted that because of JONAH's therapy practices, the plaintiffs sought help for increased depression, anxiety, and suicidal thoughts. ${ }^{148}$ The court denied JONAH's motion for partial summary judgment, emphasizing that "JONAH's conversion therapy damaged the individuals it was meant 'to cure,' any subsequent costs of repairing plaintiffs' mental or emotional health are the direct and proximate result of JONAH's actions, and hence, should be borne by JONAH." "199 The Third Circuit determined that the plaintiffs were able to recover damages sustained from the conversion therapy practices because the damage was quantifiable and could demonstrate an ascertainable loss under New Jersey's Consumer Fraud Act. ${ }^{150}$

In Ferguson v. JONAH, the plaintiffs properly established unlawful conduct by JONAH, an ascertainable loss by the plaintiffs, and a causal relationship between the unlawful conduct and the loss. ${ }^{151}$ The decision in Ferguson v. $J O N A H$ not only reaffirmed that conversion therapy is a discredited and harmful practice but also established judicial recognition of the practice as fraudulent because one cannot be cured if one is not truly sick. The Supreme Court denied certiorari in 2019, leaving the 2013 ban in place. ${ }^{152}$

Despite the persuasive Ninth and Third Circuit decisions upholding the constitutionality of conversion therapy bans, the Supreme Court in National Institute of Family and Life Advocates v. Becerra set forth a foundation for successfully challenging state conversion therapy bans. In National Institute of Family and Life Advocates v. Becerra, the Supreme Court overturned a Ninth Circuit decision. ${ }^{153}$ The Ninth Circuit previously held that the California Reproductive Freedom, Accountability, Comprehensive Care, and Transparency Act did not violate the National Institute of Family and Life Advocates' ("NIFLA") First Amendment rights by requiring the pro-life clinic to post information about contraception and abortion opportunities. ${ }^{154}$ The Ninth Circuit held that the speech being regulated was "professional speech" and, therefore, only subjected to intermediate scrutiny. ${ }^{155}$ This classification of "professional speech" was similar to the Third Circuit's decision in King v. Governor of New Jersey. ${ }^{156}$ Consequently, the Supreme Court held that "professional speech" is not

147. Id. at 135 .

148. Id. at 136 .

149. Id. at 142 .

150. See id.

151. Id. at 139.

152. Susan K. Livio, N.J. Ban on Gay-to-Straight Conversion Therapy for Kids Won't Be Overturned as U.S. Supreme Court Rejects Challenge, NJ.com (Apr. 16, 2019), https://www. nj.com/news/2019/04/nj-ban-on-gay-to-straight-conversion-therapy-for-kids-wont-be-overturnedas-us-supreme-court-rejects-challenge.html [https://perma.cc/B5A2-KFR6].

153. See Nat'l Inst. of Family \& Life Advocates v. Becerra, 138 S. Ct. 2361 (2018).

154. See id.

155. See id.

156. See King v. Governor of New Jersey, 767 F.3d 216 (3d Cir. 2014). 
a separate category of speech or subject to different rules or protections under the First Amendment. ${ }^{157}$ In a 5-4 opinion penned by Justice Thomas, the Supreme Court held that "[ $\mathrm{t}] \mathrm{his}$ Court has not recognized 'professional speech' as a separate category of speech. Speech is not unprotected merely because it is uttered by "professionals." 158 This ruling was considered a huge victory for the pro-life movement, and the State of California could not force pro-life crisis centers to include posters about state-sponsored abortion services. ${ }^{159}$

However, despite the Supreme Court finding that professional speech is not a distinct category of speech, the Supreme Court did recognize two exceptions to the strict scrutiny requirement: commercial speech and professional conduct that involves speech. ${ }^{160}$ "[C]ommercial speech relates to the compelled disclosure of 'factual and uncontroversial information.' The disclosure requirements at issue in [National Institute of Family and Life Advocates v. Becerra] did not relate to the services provided by the clinic but those by the state." ${ }^{161}$ Moreover, "[p]rofessional conduct relates to the practice of the profession. The Court found the disclosure requirements were not professional conduct: they were "not tied to a procedure at all' and so regulated 'speech as speech." "162 The Supreme Court's decision in National Institute of Family and Life Advocates v. Becerra certainly created more obstacles for states when regulating licensed professionals, however, it did not completely rule that conversion therapy bans will fail when challenged. ${ }^{163}$

The Supreme Court's decision in National Institute of Family and Life Advocates v. Becerra overturned the California decision in Pickup v. Brown in part for its classification of professional speech ${ }^{164}$ The Supreme Court decision also overturned the Third Circuit's decision in King v. Governor of New Jersey, which distinguished professional speech protections from the strict scrutiny standard. ${ }^{165}$ While the Supreme Court's decision represents, facially, a devastating verdict when considering conversion therapy bans, many First Amendment scholars are still confident that conversion therapy bans do not represent First Amendment violations. ${ }^{166}$ The decision in National Institute of Family and Life

157. Nat'l Inst. of Family \& Life Advocates, 138 S. Ct. at 2371.

158. Id. at 2371-72.

159. Emma Green, The Supreme Court Hands a Win to the Pro-Life Movement, ATLANTIC (June 26, 2018), https://www.theatlantic.com/politics/archive/2018/06/the-supreme-court-hands-awin-to-the-pro-life-movement/563738/ [https://perma.cc/UKF4-MUTH].

160. Nat'l Inst. of Family \& Life Advocates, 138 S. Ct. at 2372.; Melanie Griffith, Cities Are Turning on Conversion Therapy Bans, MinN. L. REV. (Nov. 12, 2019), https://minnesotalawreview. org/2019/11/12/cities-are-turning-on-conversion-therapy-bans/ [https://perma.cc/2YNY-XJPX].

161. Griffith, supra note 160 (footnotes omitted).

162. Id. (footnotes omitted).

163. Id.

164. See Pickup v. Brown, 740 F.3d 1208 (9th Cir. 2014).

165. See King v. Governor of New Jersey, 767 F.3d 216 (3d Cir. 2014).

166. Mark Joseph Stern, Bans on LGBTQ “Conversion Therapy” for Minors Are Now Under 
Advocates v. Becerra can be distinguished from conversion therapy bans simply on the merits of the facts. ${ }^{167}$ National Institute of Family and Life Advocates $v$. Becerra regulates "speech as speech" and does not consider speech as conduct on behalf of licensed professionals. ${ }^{168}$ Conversion therapy bans limit speech as a form of treatment or talk-therapy practice provided to a patient, not simply speech as speech or as a regulation preventing LMHPs from speaking about practice. ${ }^{169}$ Many scholars also argue that the bans represent the government's acknowledgment of a duty to regulate a medical and mental health practice that has been disavowed by every major medical and mental health organization in the United States. ${ }^{170}$ " [J] ust as doctors can be forbidden from 'treating' a broken bone by reciting the Lord's Prayer, they can be barred from 'treating' LGBTQ identity by engaging in discredited coercion." 171

\section{ARGUMENT: INDIANA HAS A DUTY TO PASS A CONVERSION THERAPY BAN FOR LICENSED MENTAL HEALTH CARE PROVIDERS}

The chorus of voices will grow each year, revealing decades of pain, decades lost, families torn apart, relationships ruined because people outside the ex-gay world can never understand what we patients went through. ${ }^{172}$

As stated previously in this Note, Hoosier youth are significantly more likely to consider or attempt suicide than their peers living in other states with one in five youth considering suicide. ${ }^{173}$ Hoosier youth who identify as a sexual orientation minority are five times more likely to attempt suicide than their heterosexual peers. ${ }^{174}$ Youth subjected to SOCE are eight times more likely to commit suicide. ${ }^{175}$ And, among Indiana's neighboring states, Indiana has the highest number of youth who have seriously considered suicide. ${ }^{176}$ Indiana also ranked forty-six in the United States, including the District of Columbia, for youth with at least one major depressive episode. ${ }^{177}$ Alarmingly, Indiana ranked

Threat Thanks to the Supreme Court, SLATE (Feb. 1, 2019), https://slate.com/news-andpolitics/2019/02/lgbtq-conversion-therapy-bans-clarence-thomas-supreme-court.html [https://perma.cc/6N85-3XS3].

167. Griffith, supra note 160.

168. Id.

169. Id.

170. Stern, supra note 166.

171. Id.

172. CONLEY, supra note 75 , at 335.

173. IND. Youth INST., supra note 33.

174. Id. at 127.

175. JUSt As They ARE, supra note 13.

176. Ind. Youth InSt., supra note 33, at 128.

177. Michele Hellebuyck et al., Mental Health Am., The State of Mental Health IN AMERICA 17 (2019), https://mhanational.org/sites/default/files/2019-09/2019\%20MH\%20in 
fiftieth in the United States in the same report for youth with severe mental depressive episodes typically triggered by depression compounded by other issues like substance abuse, anxiety, and disorderly behavior. ${ }^{178}$

There is a clear mental health concern for youth living in the State of Indiana that requires state action. The already disturbing suicide rates and mental health concerns are only exacerbated for LGBTQ youth living in the State of Indiana. It is time for Indiana to act to promote well-being for all Hoosier youth. As more and more states throughout the United States adopt conversion therapy bans, Indiana will likely become a destination state for the uncredited practice. While conversion therapy is currently banned in twenty states in the United States, only one state prevents licensed medical and mental health care providers from referring patients to other states without bans. ${ }^{179}$ Therefore, "individuals will be able to seek therapy in other states, essentially 'state-forum-shopping' to receive conversion therapy." 180 Presently, Delaware is the only state to include prohibitions in its conversion therapy ban to prevent medical and mental health care providers from referring minors to conversion therapy practitioners outside the State of Delaware. ${ }^{181}$ By not passing a conversion therapy ban in Indiana, Indiana may become responsible not only for the poor mental health outcomes experienced by Hoosier minors but also for the poor mental health outcomes of other states' youth.

Indiana has a duty to adopt a conversion therapy ban in the State, not only to protect and promote the mental health of Hoosier youth but also because the practice is not supported by any empirical evidence. Also, the practice is disavowed by all leading medical and mental health professional organizations, and Indiana has the ability and duty to regulate licensed mental health providers.

\section{A. No Empirical Evidence Proves Conversion Therapy Works}

In 2009, the APA conducted a peer review of all empirical research on treatment outcomes published from 1960 to 2007 concerning studies that used the following terms: "conversion therapy, sexual orientation, homosexuality, and exgays." 182 The APA reviewed the studies considering three aspects: the efficacy, safety, and harm of SOCE. ${ }^{183}$ Generally, the APA "found that the low quality of the research on SOCE [was] such that claims regarding its effectiveness and widespread applicability must be viewed skeptically." 184 The APA addressed the methodological problems with SOCE research, asserting that "limitations in

\%20America\%20Final.pdf [https://perma.cc/S74A-RHZC].

178. Id. at 19.

179. Assil, supra note 102, at 569-70.

180. Id.

181. Del. Code AnN. tit. 24, § 3510(d) (2020).

182. GlASSGOLD ET AL., supra note 39, at 27 (emphasis omitted).

183. Id.

184. Id. 
making casual claims due to threats to internal validity (such as sample attrition, use of retrospective pretests); lack of construct validity, including definition and assessment of sexual orientation; and variability of study treatments and outcome measures" made the findings unreliable and unpersuasive to support that SOCE is effective. ${ }^{185}$ The APA also analyzed the efficacy and potential harm of SOCE and determined that studies "indicate that attempts to change sexual orientation may cause or exacerbate distress and poor mental health in some individuals, including depression and suicidal thoughts. The lack of rigorous research on the safety of SOCE represents a serious concern ...." "186

The APA uncovered that the available research did not address diverse populations and the overwhelming majority of individuals studied represented religious-conservative Caucasian men who sought out SOCE. ${ }^{187}$ The limited and lack of diversity in the population size of those studies also demonstrated that the participants' motivation to change helped shape the self-reports of perceived sexual orientation change. ${ }^{188}$ The limited population group of research also demonstrated that those who seek out SOCE report a higher motivation to change, which led to a positive impact on the participants' perceived change in sexual orientation. ${ }^{189}$ However, the APA noted that the various studies indicated "that those who were less religious were more likely to perceive themselves as having an LGB sexual orientation after the intervention." 190 The conflicting results between religiously motivated participants and non-religious participants clearly shaped the perceived sexual orientation change in self-reports, but do not represent an actual change. ${ }^{191}$

Alongside the underwhelming evidence that the tactics used in SOCE were casually connected to actual changes in sexual orientation, the APA reviewed studies from 2002 and 2004, which demonstrated the harm the practice causes. ${ }^{192}$ The studies described the detrimental harm that many of the participants experienced through SOCE, which included increased confusion, guilt, selfhatred, depression, suicidality, and decreased self-esteem. ${ }^{193}$ Also, although the studies reported some benefits associated with patient participation, the APA noted that such might be related to therapy techniques outside the traditional SOCE structure and that these benefits "can [also] be provided within an affirmative and multiculturally competent framework." 194

The lack of evidence and identifiable positive outcomes led the APA to

185. Id. at 34 .

186. Id. at 42 .

187. Id. at 45 .

188. Id at 50 .

189. Id.

190. Id.

191. Id.

192. Id.

193. Id.

194. Id. at 3. Such a framework "mitigate[s] the harmful aspects of SOCE by addressing sexual stigma while understanding the importance of religion and social needs." Id. 
firmly reject the practice of SOCE. ${ }^{195}$ In doing so, the APA stated that it "consider[s] it inappropriate for psychologists and other LMHP to foster or support in clients the expectation that they will change their sexual orientation if they participate in SOCE." 196 The APA denounced the practice because it operates based on a foundation that is inconsistent with the scientific and professional consensus that homosexuality is a mental disorder requiring treatment. ${ }^{197}$

The APA asserted that SOCE violates the general principles that guide and govern psychologists. ${ }^{198}$ Providing SOCE services would directly conflict with Principle A of the APA Ethics Code, which "establishes that psychologists aspire to provide services that maximize benefit and minimize harm." 199 The APA noted that the practice reinforces the stigma and discrimination against the LGBTQ community. ${ }^{200}$ The APA also found that SOCE comes into conflict with Principle $\mathrm{E}$, self-determination, which is defined as "the process by which a person controls or determines the course of her or his own life." ${ }^{201}$ The APA recognized that clients have a right to designate their own treatment. ${ }^{202}$ However, LMHPs providing SOCE, despite the harmful impact, would not promote client selfdetermination. ${ }^{203}$ The LMHP would be neglecting her responsibility to provide competent assessments and interventions that benefit the client rather than harm the client. ${ }^{204}$ The APA advocated for LMHPs to respect and understand religious diversity and how the client's religious relationship impacts the client's worldview of the LGBTQ community, however, the LMHP should focus on the scientific evidence and use her professional judgment in determining proper mental health interventions. ${ }^{205}$

Narrowing the scope to minor children, the APA firmly asserted that it "conclude[d] that there is no existing research to support the hypothesis that psychotherapy in children alters adult sexual orientation." 206 The APA recommended that LMHPs practice affirmative therapeutic interventions for LGBTQ minors seeking a change in their sexual orientation or their behavioral

195. Id. at 66 .

196. Id.

197. Id.

198. Id. at 67 .

199. Id.; see also AM. Psychol. Ass'N, Ethics PrinciPles of Psychologists ANd Code OF CONDUCT 3 (2017), https://www.apa.org/ethics/code/ethics-code-2017.pdf [https://perma.cc/TPT3$\mathrm{BXFB]}$.

200. GLASSGOLD ET AL., supra note 39, at 67.

201. Id. at 66 .

202. Id. at 69 .

203. Id.

204. Id.

205. Id. at 70 .

206. Id. at 73 . 
expression. ${ }^{207}$ The APA also endorsed identity exploration and development, which includes "offering permission and opportunity to explore a wide range of options and reducing the conflicts caused by the dichotomous or conflicting conceptions of self and identity without prioritizing a particular outcome." ${ }^{208}$ This approach supports helping religious individuals with same-sex attractions explore options. ${ }^{209}$

Typically the practice of identity exploration and development is excluded from state bans on conversion therapy. ${ }^{210}$ The APA recommended that LMHPs provide support to children and youth in their developmental processes and milestones, reduce internalized stigmas in children and the stigmas held by their parents, and provide affirming information and education on LGBTQ identities and lives. ${ }^{211}$ Any interventions outside of affirmation therapy or identity exploration produced "serious concerns that the coercive or involuntary treatment of children or adolescents has the potential to be harmful and may potentially violate current clinical and practice guidelines, standards for ethical practice, and human rights." 212

The APA's research and opinions regarding conversion therapy, guided other organizations, including the Pan American Health Organization to denounce the practice in 2012. ${ }^{213}$ The international public health agency asserted that "[h] $[\mathrm{h}$ ophobic ill-treatment on the part of health professionals or other members of health care teams violates human rights obligations .... Such treatment is unacceptable and should not be tolerated." 214

Most recently, the American Medical Association ("AMA") voted in 2019 to support state and federal efforts to ban conversion therapy. Dr. William E. Kobler, an AMA board member, stated that "conversion therapy needs to end in the United States given the risk of deliberate harm to LGBTQ people . . . . Conversion therapy has no foundation as scientifically valid medical care and lacks credible evidence to support its efficacy or safety." 15 In the AMA's brief rejecting conversion therapy, the AMA outlined the following ethical concerns regarding the practice.

207. Id. at 79-80.

208. Id. at 4 .

209. Marie-Amélie George, Expressive Ends: Understanding Conversion Therapy Bans, 68 AlA. L. ReV. 793, 797 (2017).

210. Id.

211. GLASSGOLD ET AL., supra note 39 , at 80.

212. Id. at 86 .

213. Pan Am. Health Org., "Cures” for an Illness That Does Not Exist 3 (2012), https://www.paho.org/hq/dmdocuments/2012/Conversion-Therapies-EN.pdf [https:/perma.cc/ AT9V-GDMM].

214. Id.

215. Tim Fitzsimons, American Medical Association Backs Nationwide Conversion Therapy Ban, NBC News (Nov. 21, 2019), https:/www.nbcnews.com/feature/nbc-out/american-medicalassociation-backs-nationwide-conversion-therapy-ban-n1088731 [https://perma.cc/KPN3-2Y79]. 
[A]dminstering change efforts is an inherently discriminatory practice often administered coercively and fraught with ethical problems, such as:

- Uninformed consent: change efforts are often prescribed without full descriptions of risk and disclosure of lack of efficacy or evidence

- Breaches of confidentiality: content of treatment, sexual orientation and gender identity may be shared with family, school or religious leaders without proper consent

- Patient discrimination: change efforts reinforce bias, discrimination and stigma against LGBTQ individuals

- Indiscriminate and improper treatment: change efforts are recommended regardless of evidence

- Patient blaming: the failure of treatment may be blamed on the patient

It is clinically and ethically inappropriate for health care providers to direct mental or behavioral health interventions, including SOCE and [Gender Identity Change Efforts], with a prescriptive goal aimed at achieving a fixed development outcome of a child's or adolescent's sexual orientation, gender identity or gender expression. ${ }^{216}$

In the AMA's issue brief, the organization outlined a clear commitment to the LGBTQ community by adding an explicit opposition to conversion therapy to a recent AMA policy, which states that the organization "opposes, the use of 'reparative' or 'conversion' therapy of sexual orientation or gender identity." 217 The issue brief also outlined the AMA's commitment to educate physicians on the needs of the LGBTQ population, increase physician competency on LGBTQ health issues, and to collaborate with other organizations to streamline education and research on mutual concerns impacting the LGBTQ community. ${ }^{218}$ "Historically, medical professionals have contributed to the stigmatization of LGBTQ individuals, so the AMA's active involvement in LGBTQ health advocacy is incredibly important . ...".219

Despite the lack of credible or empirical evidence to support the notion that conversion therapy is effective, prominent former leaders of conversion therapy have also discredited it. Notably, in 2013, John Paulk, a former chairman of Exodus International and acclaimed conversion therapy success story, came out

216. LGBTQ Change Efforts (So-Called Conversion Therapy), AMA 3 (2019), https:// www.ama-assn.org/system/files/2019-12/conversion-therapy-issue-brief.pdf [https://perma.cc/J8S6F9J6].

217. Id. at 4 .

218. See id. at 4-5.

219. Fitzsimons, supra note 215. 
as gay. ${ }^{220}$ In his formal apology, Paulk wrote, "Parents, families, and their loved ones were negatively impacted by the notion of reparative therapy and the message of change. I am truly, truly sorry for the pain I have caused." ${ }^{221}$ Shortly thereafter, Alan Chambers, the leader of Exodus International also rejected conversion therapy, which led to the organization closing. ${ }^{222}$ In 2014, nine former leaders of leading conversion therapy organizations, including LIA and Exodus International, released a letter acknowledging the pain and hurt they personally caused and denounced the practice of conversion therapy. ${ }^{223}$ "As former 'ex-gay' leaders, having witnessed the incredible harm done to those who attempted to change their sexual orientation or gender identity, we join together in calling for a ban on conversion therapy." 224

Since the 2014 letter, other former leaders have come out not only in opposition to conversion therapy but also as part of the LGBTQ community. Recently, McKrae Game, the leader of Hope for Wholeness, David Matheson, a former Mormon conversion therapist, and also Randy Thomas, the former executive director of Exodus International, have all come out against conversion therapy. ${ }^{225}$ Game also exposed the deceptive nature of conversion therapy, stating that "[c]onversion therapy is not just a lie, but it's very harmful ... [b]ecause it's false advertising." 226

Based on the lack of empirical evidence for conversion therapy's efficacy, the overwhelming majority of leading medical and mental health care professional organizations advocating to ban conversion therapy, and the testimony and confessions of prominent ex-conversion therapy leaders, Indiana should ban the practice of conversion therapy for LMHPs in the State.

220. Katie McDonough, Conversion Therapy Advocate Issues Formal Apology, Renounces “Ex-Gay” Past, SAlON (Apr. 25, 2013), https://www.salon.com/2013/04/25/conversion_therapy_ advocate_issues_formal_apology_renounces_ex_gay_past/[https://perma.cc/7GEL-4G3U].

221. Id.

222. Tim Fitzsimons, 'Doesn't Surprise Me': Conversion Therapy Survivors on Another ExTherapist Coming Out, NBC NEws (Sept. 4, 2019), https:/www.nbcnews.com/feature/nbcout/doesn-t-surprise-me-conversion-therapy-survivors-another-ex-therapist-n 1049781 [https://perma.cc/9RY2-VQV3] [hereinafter Doesn 't Surprise Me]

223. Former Ex-Gay Leaders Unite in Opposition to Conversion Therapy, NAT'L CTR. FOR LESBIAN RTS., http://www.nclrights.org/former-ex-gay-leaders-unite-in-opposition-to-conversiontherapy/ [https://perma.cc/393Y-MFS8] (last visited Mar. 29, 2020).

224. Id.

225. Mahita Gajanan, 'I Was a Religious Zealot That Hurt People.' After Coming Out as Gay, a Former Conversion Therapy Leader is Apologizing to the LGBTQ Community, TIME (Sept. 4, 2019), https://time.com/5668351/mckrae-game-comes-out-gay-conversion/ [https://perma.cc/4TZLQPUC]; Doesn't Surprise Me, supra note 222.

226. Michael Majchrowicz, Conversion Therapy Leader for 2 Decades, McKrae Game Disavows Movement He Helped Fuel, Post \& Courier (Aug. 30, 2019), https://www. postandcourier.com/news/conversion-therapy-leader-for-2-decades-mckrae-game-disavowsmovement-he-helped-fuel/article_fb56dcfc-c384-11e9-970d-bb9a2a8656c5.html [https://perma.cc/8KYA-E66P]. 


\section{B. Indiana Has a Duty to Regulate Licensed Health Providers}

Indiana has a duty and is permitted to regulate LMHPs to promote the best health outcomes for Hoosier residents. Title 25 of the Indiana Code has clear and explicit guidelines regulating different licensed professionals in the State of Indiana. ${ }^{27}$ The Indiana Code outlines regulations for licensed medical professionals, nurses, psychologists, behavioral health and human services, and other licensed professions. ${ }^{228}$ These codified regulations include governing medical and mental health professions to protect Indiana residents from unlawful and unethical practices. ${ }^{229}$

This Note section will focus on the Indiana Code provisions that apply to marriage and family therapists, and it examines the 2019 politics. ${ }^{230}$ Section $25-1$ 9-6.7 of the Indiana Code gives the State the power to exercise sanctions upon licensed practitioners, more narrowly, marriage and family therapists, if the practitioner performs conduct in direct violation of the statute. ${ }^{231}$ The practice of conversion therapy directly violates many of the outlined provisions of conduct that would subject a practitioner to sanctions under Indiana law.

LMHPs are in direct violation of section 25-1-9-6.7(2) of the Indiana Code when the LMHP "fail[s] to meet the minimum standards of performance in professional activities when measured against generally prevailing peer performance in professional activities, including the undertaking of activities that the practitioner is not qualified by training or experience to undertake."232

The practice of conversion therapy by LMHPs would be a direct violation of this section because no educational curriculum for LMHPs includes conversion therapy ${ }^{233}$ Many institutions actually present and instruct the exact opposite of practicing conversion therapy. ${ }^{234}$ The APA only advocates for affirmative, not conversion, therapy programs for minors seeking guidance for sexual orientation and gender expression identity struggles. ${ }^{235}$ Therefore, any licensed therapist claiming to provide conversion therapy is acting in direct conflict with the therapist's education and training. ${ }^{236}$ It would be reckless for the State of Indiana to allow licensed professionals to practice a therapy without qualified training, certified education, or experience, especially on vulnerable minor children.

Section 25-1-9-6.7(3) of the Indiana Code also comes into direct conflict,

227. See IND. CODE $§ 25-0.5-8$ (2020).

228. See IND. CODE § 25-0.5-8-11, 12, 17, 25 (2020).

229. Id.

230. See Lange, supra note 21.

231. IND. CODE $\S 25-1-9-6.7$ (2020).

232. IND. CODE $\S 25-1-9-6.7(2)$ (2020).

233. Assil, supra note 102, at 572.

234. Id.

235. GLASSGOLD ET AL., supra note 39, at 79-80.

236. Assil, supra note 102, at 572. 
stating that a licensed therapist is subject to sanctions if the LMHP "performed services, including any duties required of the individual . . . in reckless disregard of the best interests of a patient, a client, or the public." ${ }^{237}$ Overwhelmingly, the majority of leading medical and mental health care organizations recognize the detrimental impact conversion therapy has on the LGBTQ community. ${ }^{238}$ Any form of conversion therapy is reckless and directly goes against the individual patient's positive health care needs. 'Institutions offering such 'treatment' at the margin of the health sector should be viewed as infringing the right to health by assuming a role properly pertaining to the health sector and by causing harm to individual and community well-being." ${ }^{239}$ Indiana has a duty to ban this so-called therapy to prevent the potential harm patients will experience if allowed to be subjected to the treatment.

Section 25-1-9-6.7(8) of the Indiana Code would also support a conversion therapy ban. This section subjects therapists to discipline for "willfully plant[ing] in the mind of [a] patient suggestions that are not based in facts known to the [therapist]." ${ }^{920}$ For an LMHP to suggest that she specializes in conversion therapy or practices conversion therapy would plant in the mind of a patient a false impression, and such is dishonest. ${ }^{241}$ " $[\mathrm{A}]$ mental health practitioner who advertises their ability to 'cure' patients that have homosexual attractions is deceptive because they are fraudulently misleading their patients and fabricating unjustified expectations that there is an antidote for being gay." ${ }^{242}$ By allowing LMHPs to promote the unfounded notion that they can change an individual's sexuality or gender identity is impractical and creates a gross misrepresentation not supported by any factual evidence. ${ }^{243}$

Finally, a conversion therapy ban in Indiana would be supported by section 25-1-9-6.7(9) of the Indiana Code, which permits sanctions if the LMHP "performed services outside of the scope of practice of the license."244 Section 2523.6-1-7 specifies LMHPs to provide therapy that coincides with classifications in the Diagnostic and Statistical Manual of Mental Disorders and to the extent of the LMHP's "education, training, experience, and scope of practice." 245 The Diagnostic and Statistical Manual of Mental Disorders has not classified homosexuality as a mental disorder since 1973, and no accredited educational curriculums provide training on conversion therapy. ${ }^{246}$ Clearly, this section supports a ban on conversion therapy. It is well-defined from the Indiana Code sections that Indiana has the ability and the duty to regulate the practices

237. IND. CODE $§ 25-1-9-6.7(3)$ (2020).

238. See Lies and Dangers, supra note 20.

239. Pan Am. HeAlth ORG., supra note 213 (footnote omitted).

240. IND. CODE § 25-1-9-6.7(8) (2020).

241. Assil, supra note 102, at 573-74.

242. Id. at 572 .

243. Id. at 574 .

244. IND. CODE § 25-1-9-6.7(9) (2020).

245. IND. CODE $\S 25-23.6-1-7$ (2020).

246. SAMHSA, supra note 2 , at 15. 
performed by LMHPs in the State. A conversion therapy ban also would protect LMHPs from being subjected to sanctions of disciplinary action because a ban would absolve LMHPs from any pressure from clients to provide the therapy for the client's minor children. The LMHP would be legally obligated not to practice the detrimental therapy. It would not be an overstep by the Indiana Legislature to prohibit LMHPs from practicing conversion therapy because the practice is fundamentally at odds with what Indiana tries to eliminate from practicing LMHPs in the State. Therefore, the State of Indiana should amend section 2523.6-11 of the Indiana Code to include conversion therapy as a prohibited practice because the Indiana Code has already provided a strong foundation to regulate LMHPs in the State.

Indiana also is permitted to limit what is deemed a permissible practice provided by LMHPs if the limitation or ban serves to protect the public's health, safety, and welfare. ${ }^{247}$ The authority for states to regulate LMHPs is furnished by the Tenth Amendment. ${ }^{248}$ The Tenth Amendment, which provides states with their police power authority, has been used to justify reporting laws, which require clinicians to report public health risks because the laws and regulations serve the welfare of the public. ${ }^{249}$ The Tenth Amendment has also afforded states the ability to limit individual liberties when necessary to safeguard the public's health and safety. ${ }^{250}$

In Jacobson v. Massachusetts, the Supreme Court acknowledged the states' rights to regulate certain activities within their state lines, as long as such did not impact the people in other states; "[a]ccording to settled principles, the police power of a state must be held to embrace, at least, such reasonable regulations established directly by legislative enactment as will protect the public health and the public safety." 251 The Supreme Court further elaborated that the "manner in which those results are to be accomplished is within the discretion of the state . . . only to the condition that no rule prescribed by a state. . . shall contravene the Constitution of the United States, nor infringe any right granted or secured."252 A conversion therapy ban would clearly promote public health and welfare in the State of Indiana.

Conversely, opponents of conversion therapy bans traditionally argue that the bans violate the First Amendment rights of LMHPs, including infringement upon the freedoms of speech and religion. However, a conversion therapy ban seeks to regulate licensed therapy conduct and does not aim to restrict freedom of speech

247. Janet L. Dolgin, Physician Speech and State Control: Furthering Partisan Interests at the Expense of Good Health, 48 New ENG. L. REv. 293, 322 (2014).

248. U.S. Const. amend. X. ("The powers not delegated to the United States by the Constitution, nor prohibited by it to the States, are reserved to the States respectively, or to the people.")

249. Dolgin, supra note 247, at 336-37.

250. Jacobson v. Massachusetts, 197 U.S. 11, 25 (1905).

251. Id.

252. $I d$. 
or freedom of religion. ${ }^{253}$ In the twenty states with conversion therapy bans, LMHPs are only prevented from practicing conversion therapy, the bans do not prevent the LMHP from discussing conversion therapy, expressing their views on the practice, recommending patients to unlicensed conversion therapists, nor does it prevent LMHPs from providing conversion therapy to adults seeking the treatment who are over the age of eighteen. ${ }^{254}$

In an amicus brief written by First Amendment Scholars submitted to the Ninth Circuit in Pickup v. Brown, the scholars laid out the foundation that permitted the State of California to allow a conversion therapy ban to stand against challenges of infringement of First Amendment rights. ${ }^{255}$ The scholars cited the Supreme Court's holding in Giboney v. Empire Storage \& Ice Co., which asserted that "it has never been deemed an abridgment of freedom of speech or press to make a course of conduct illegal merely because the conduct was in part initiated, evidenced, or carried out by means of language, either spoken, written, or printed." ${ }^{256}$ Therefore, it would not be an infringement upon LMHPs to prohibit conversion therapy because, even though the practice mainly consists of talk therapy today, the State of Indiana still has the right to regulate the harmful spoken conduct.

The First Amendment scholars also cited another Supreme Court holding that demonstrated that the rule provided in Giboney applied to all areas of conduct. ${ }^{257}$ In Ohralik v. Ohio State Bar Association, the Supreme Court held that "the State [did] not lose its power to regulate commercial activity deemed harmful to the public simply because speech [was] a component of that activity." 258 Similarly, conversion therapy is a commercial and professional activity that has been deemed harmful to those subjected to it, which enables state intervention. It does not promote positive mental health outcomes for its patients and only perpetuates negative social stigmas around the LGBTQ identity and also fosters homophobia and transphobic ideologies. Therefore, the State of Indiana is well within its right to prohibit the practice.

The amicus brief equated the regulation of LMHPs to doctors in malpractice suits by arguing that "[a] doctor surely could not evade a malpractice liability for giving incompetent medical advice - say, advising a patient to take up smoking because the doctor believes it to be healthy . . . by claiming it was speech and thus protected by the First Amendment." 259 It would be hypocritical to provide

253. George, supra note 209 , at 823.

254. Tiffany Graham, Conversion Therapy: A Brief Reflection on the History of the Practice and Contemporary Regulatory Efforts, 52 CREIGHTON L. ReV. 419, 424-25 (2019).

255. See Brief for Amicus Curiae of First Amendment Scholars in Support of DefendantsAppellees Supporting Affirmance at 7, Pickup v. Brown, 740 F.3d 1208 (9th Cir. 2014) (No. 1217681).

256. Id. (quoting Giboney v. Empire Storage \& Ice Co., 336 U.S. 490, 502 (1949)).

257. $I d$.

258. Ohralik v. Ohio State Bar Ass'n, 436 U.S. 447, 456 (1978) (holding that the State was able to prohibit solicitation by lawyers).

259. Brief for Amicus Curiae of First Amendment Scholars in Support of Defendants- 
First Amendment protections to one licensed profession and not another, especially when both licensed professions have the potential to drastically and dramatically impact the health outcomes of their patients.

Therefore, Indiana, through the powers vested by the Tenth Amendment and as proscribed by the Supreme Court, ${ }^{260}$ is permitted to ban conversion therapy. A conversion therapy ban would serve the public health and welfare needs of Hoosier residents because the ban seeks to prohibit a practice that is not founded on promoting and achieving positive health outcomes nor is it supported by evidence-based research.

\section{Indiana Has a Duty to Protect LGBTQ Youth}

Indiana has a duty to protect LGBTQ youth and should outlaw harmful therapy practices designed to target and eliminate their existence. Youth living in the State of Indiana are significantly more likely to consider or attempt suicide than their peers nationally. ${ }^{261}$ And youth living in the State of Indiana that identify as LGBTQ are five times more likely than their heterosexual peers to commit suicide. ${ }^{262}$ It is estimated that 16,000 LGBTQ youth will be subjected to conversion therapy in the United States in states without conversion therapy bans. ${ }^{263}$ In a national survey conducted by the Trevor Project, two-thirds of LGBTQ youth reported that someone tried to change their gender identity or sexual orientation. ${ }^{264} 32 \%$ of the LGBTQ youth respondents reported a suicide attempt within the past year after undergoing conversion therapy. ${ }^{265}$

According to a recent Indiana Youth Institute report, teen suicide in Indiana ranks among one of the highest in the nation. ${ }^{266}$ Based on these statistics, the State of Indiana should take action to prevent and reduce the number of teen suicide deaths in the State, regardless of a minor's sexual orientation or gender identity.

Appellees Supporting Affirmance, supra note 255, at 7.

260. Without infringing upon the First Amendment, the Supreme Court vests power in the states to regulate speech when deemed actual conduct.

261. IND. YouTh INST., supra note 33.

262. Id.

263. MALLORY ET AL., supra note 18.

264. Landmark Study Finds 39 Percent of LGBTQ Youth and More than Half of Transgender and Non-Binary Youth Report Having Seriously Considered Suicide in the Past Twelve Months, TREVOR ProjeCt (June 11, 2019), https://www.thetrevorproject.org/trvr_press/landmark-studyfinds-39-percent-of-lgbtq-youth-and-more-than-half-of-transgender-and-non-binary-youth-reporthaving-seriously-considered-suicide-in-the-past-twelve-months/ [https://perma.cc/6ENE-DEZB]. The Trevor Project's National Survey on LGBTQ Youth Mental Health is the largest survey ever conducted on the mental health of LGBTQ youth. Id. The survey included nearly 35,000 LGBTQ youth respondents between the ages of twelve and twenty-four from every state of the United States. Id.

265. Id.

266. IND. Youth INST., supra note 33, at 1. 
Conversion therapy bans "are much more than the four corners of their pages."267 Conversion therapy bans provide expressed acknowledgment and validation to the LGBTQ identity, which changes minds and saves lives. "Conversion therapy bans send a message to LGBT youth: "Our state . . does not see you as "sick" and in need of a cure. We will not allow practitioners to attempt to change you, even if your parents want them to. We see you, and we will protect you.'"268 By not banning the practice, Indiana indirectly endorses the practice of conversion therapy and demonstrates its lack of care for LGBTQ youth.

Public opinion would also support a conversion therapy ban. In 2014, a national poll revealed that $63 \%$ of Americans believe that conversion therapy does not change a person's sexual identity from gay to straight. ${ }^{269}$ Recent polls in Arizona, Florida, New Mexico, North Carolina, Pennsylvania, and Virginia revealed strong support for conversion therapy bans on youth by LMHPs. ${ }^{270}$ More recently, a 2019 national poll found that $56 \%$ of adults in the United States support making the practice of conversion therapy on youth by LMHPs illegal. ${ }^{271}$ This shift in opinion, along with the growing amount of states banning the practice, represents sweeping support that the so-called therapy is ineffective, outdated, and dangerous.

\section{CONCLUSION}

Eliminating the practice of conversion therapy on sexual and gender minority minors is an important step in promoting better mental health outcomes and health outcomes in general for LGTBQ youth. While banning conversion therapy will not completely eliminate the gap in mental health outcomes between LGBTQ youth and their heterosexual peers, it will be an important step in the right direction to prevent LGBTQ youth from being exposed to outdated stereotypes, feelings of rejection through the veil of therapy, and will eliminate societal bias. $^{272} \mathrm{~A}$ conversion therapy ban in the State of Indiana would not only protect vulnerable LGBTQ minors but it would also - through the ban's expressive

267. George, supra note 209 , at 830 .

268. Griffith, supra note 160.

269. Peter Moore, Only $8 \%$ of Americans Think Gay Conversion Therapy Works, YouGov (June 12, 2014), https://today.yougov.com/topics/lifestyle/articles-reports/2014/06/12/gayconversion-therapy [https://perma.cc/QHR2-RGWX].

270. MALLORY ET AL., supra note 18.

271. Stonewall Anniversary Poll 06.06.2019, IPSOS (June 6, 2019), https://www.ipsos. $\mathrm{com} / \mathrm{sites} / \mathrm{default} / \mathrm{files} / \mathrm{ct} / \mathrm{news} /$ documents/2019-06/2019_reuters_tracking_-_stonewall_ anniversary_poll_06_07_2019.pdf[https://perma.cc/5AKM-FWZB]. The survey includes responses from roughly 2,237 adults age eighteen and older from the United States. Id. It also includes 1,972 registered voters who identify as either Democrat, Independent, or Republican. Id.

272. SAMHSA, supra note 2 , at 3. 
impact - promote eliminating homophobia and negative stigmas generally. ${ }^{273}$ With Indiana's minor youth suicide rates exceeding national averages, Indiana should join the twenty other states in banning the detrimental practice. ${ }^{274}$ Therefore, Indiana should pass a conversion therapy ban for LMHPs to confirm its commitment to promoting a healthier and happier Hoosier State and to support LGBTQ youth.

273. See George, supra note 209.

274. See Ind. Youth Inst., supra note 33. 